\title{
Short-term responses of unicellular planktonic eukaryotes to increases in temperature and UVB radiation
}

\author{
Isabelle Domaizon ${ }^{1 *}$, Cécile Lepère ${ }^{2}$, Didier Debroas ${ }^{2}$, Marc Bouvy $^{3}$, Jean Francois Ghiglione ${ }^{4}$, Stephan Jacquet ${ }^{1}$, \\ Yvan Bettarel $^{3}$, Corinne Bouvier ${ }^{3}$, Jean Pascal Torréton ${ }^{3}$, Francesca Vidussi ${ }^{3}$, Behzad Mostajir ${ }^{3}$, Amy Kirkham ${ }^{1}$, \\ Emilie LeFloc' $h^{3}$, Eric Fouilland ${ }^{3}$, Helene Montanié ${ }^{5}$ and Thierry Bouvier ${ }^{3}$
}

\begin{abstract}
Background: Small size eukaryotes play a fundamental role in the functioning of coastal ecosystems, however, the way in which these micro-organisms respond to combined effects of water temperature, UVB radiations (UVBR) and nutrient availability is still poorly investigated.

Results: We coupled molecular tools (18S rRNA gene sequencing and fingerprinting) with microscope-based identification and counting to experimentally investigate the short-term responses of small eukaryotes ( $<6 \mu \mathrm{m}$; from a coastal Mediterranean lagoon) to a warming treatment $\left(+3^{\circ} \mathrm{C}\right)$ and UVB radiation increases $(+20 \%)$ at two different nutrient levels. Interestingly, the increase in temperature resulted in higher pigmented eukaryotes abundances and in community structure changes clearly illustrated by molecular analyses. For most of the phylogenetic groups, some rearrangements occurred at the OTUs level even when their relative proportion (microscope counting) did not change significantly. Temperature explained almost $20 \%$ of the total variance of the small eukaryote community structure (while UVB explained only 8.4\%). However, complex cumulative effects were detected. Some antagonistic or non additive effects were detected between temperature and nutrients, especially for Dinophyceae and Cryptophyceae.
\end{abstract}

Conclusions: This multifactorial experiment highlights the potential impacts, over short time scales, of changing environmental factors on the structure of various functional groups like small primary producers, parasites and saprotrophs which, in response, can modify energy flow in the planktonic food webs.

Keywords: Small eukaryotes, Molecular diversity, Temperature, UVB radiation, Microcosms experiment, Mediterranean lagoon

\section{Background}

Small-sized plankton plays critical roles in aquatic systems, mostly as major contributors to production and biomass, and as key players driving carbon and nutrient cycles [1,2]. The study of the gene coding for $18 \mathrm{~S}$ rRNA has brought opportunities to investigate the eukaryotic composition in the smallest size fraction in various aquatic systems, independently of morphological identification and cultivation [3-7]. The molecular characterization of

\footnotetext{
* Correspondence: isabelle.domaizon@thonon.inra.fr

'INRA, UMR 42 CARRTEL, 75 avenue de Corzent, BP511, Thonon-les-bains F-74200, France

Full list of author information is available at the end of the article
}

small (pico and/or nano) eukaryotic assemblages has highlighted an unexpected phylogenetic and functional diversity (e.g. [8-11]), and many important questions are now emerging about the in situ dynamics of diverse eukaryotic groups, and the regulatory factors that drive changes in their structure.

A few studies have investigated the effects of structuring factors on the molecular diversity of small eukaryotes, and shown that trophic status, predation by met zooplankton, and/or viral lytic activity are involved in the regulation of the eukaryotic microbial assemblage [5,12-15]. However, combined effects of physical factors, such as water temperature and UVB radiation (UVBR:

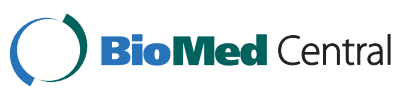


$280-320 \mathrm{~nm}$ ) are still poorly investigated. It is recognized that either temperature or UVBR increases can modify microbial dynamics and structure at various levels (species, population, trophic network) (e.g. [16-20]). Nevertheless, previous investigations have generally focused on only one specific stressor and little is known about the combined effects of climatic and anthropogenic stressors on diversity and food web structure. Since these stressors are expected to exert complex interactive effects [21-23], multi-factorial studies are required to improve the understanding of the mechanistic basis underlying ecological responses of planktonic food webs to these regulatory factors. A series of enclosure experiments using natural microbial communities from the Mediterranean Thau lagoon were recently performed to assess the response of microbial communities to topdown and bottom-up control under various simulated climatic conditions (temperature and UVBR) [24]. This study showed a much larger effect of temperature than UVBR on bacterial dynamics. In addition to this study, in order to describe the composition of small eukaryotes and potentially to observe changes in their structure, we used a similar microcosm experiment to tease apart the effects of single and combined increase of temperature $\left(+3^{\circ} \mathrm{C}\right)$ and UVBR (+20\%), at two different nutrients levels. Here, we investigate short-term responses of both pigmented and non-pigmented small eukaryotes (size fraction $<6 \mu \mathrm{m}$ ) to these simulated climatic conditions by using morphological and molecular methods (18S rRNA gene sequencing and a fingerprint technique: Capillary Electrophoresis Single Strand Conformation Polymorphism CE-SSCP).

The increases in temperature and UVBR tested in this study correspond to the mean temperature increase expected in the Mediterranean region by 2080-2099 (IPCC 2007) and the high-UVBR scenario for the European region during spring in future years [22]. This approach enables us to describe the short term responses of eukaryotic community assemblages when exposed to these drivers during the productive spring season. The changes induced by these regulatory factors could be detected at different taxonomic levels thanks to the coupling of morphological and molecular approaches.

\section{Methods}

\section{Experimental design}

The four-day experiment (20-23 April 2006) was conducted on the Mediterranean platform for Marine Ecosystems Experimental Research (MEDIMEER) located in Sète (France) on the shore of the Thau lagoon $\left(43^{\circ}\right.$ $\left.249^{\prime \prime} \mathrm{N}, 3^{\circ} 41^{\prime} 19^{\prime \prime} \mathrm{E}\right)$. The experimental platform was composed of submerged enclosures (1.2 m diameter and $2 \mathrm{~m}$ depth) which allowed the isolation of up to $2,000 \mathrm{~L}$ and the simulation of UVBR and temperature increases in order to study the responses of pelagic communities to these manipulated factors simultaneously. The regulations of UVBR and temperature are performed with high frequency monitoring following the in situ temperature and natural incident UVBR (see details in supplementary data; full description in Nouguier et al. [25]).

Four enclosures, filled with lagoon surface-water at random, were used as incubators for the $2 \mathrm{~L}$ experimental bags (UV-permeable sterile Whirl Pack ${ }^{\circledR}$ polyethylene bags incubated at subsurface) in which microbial communities were isolated. The factorial experimental design constituted eight different treatments (each being tested in three replicates): $\mathbf{C}$ : control, $\mathbf{C}+\mathbf{N u t}$ : control with nutrient addition, UV: UVBR increase $(+20 \%)$, UV + Nut: UVBR increase $(+20 \%)$ and nutrient addition, $\mathbf{T}$ : temperature increase $\left(+3^{\circ} \mathrm{C}\right), \mathbf{T}+\mathbf{N u t}$ : temperature increase $\left(+3^{\circ} \mathrm{C}\right)$ and nutrient addition, TUV: temperature $\left(+3^{\circ} \mathrm{C}\right)$ and UVBR $(+20 \%)$ increases, TUV + Nut: temperature $\left(+3^{\circ} \mathrm{C}\right)$ and UVBR increases $(+20 \%)$ and nutrient addition (Figure 1).

In order to fill the 24 Whirl Pack bags, $100 \mathrm{~L}$ subsurface lagoon water was pumped and pre-filtered through 6 - $\mu \mathrm{m}$-pore-size polycarbonate membranes $(47 \mathrm{~mm}$ in

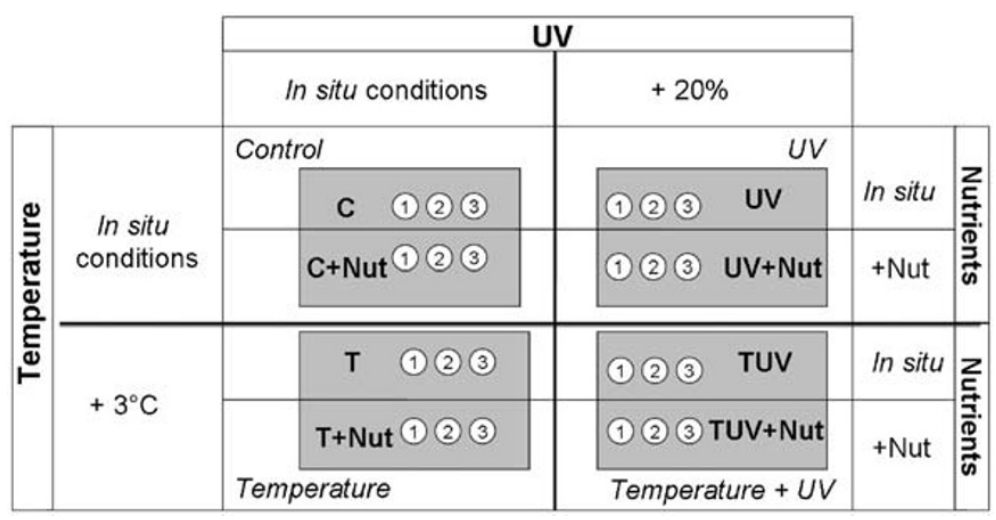

Figure 1 Crossed factorial experimental design conducted to assess the effects of the three regulatory factors: (Temperature, UVB radiation and nutrient increases). 
diameter) in order to isolate the smallest planktonic fraction. This water sample $(<6 \mu \mathrm{m})$ was equally distributed into 24 sterile Whirl Pack ${ }^{\circledR}$ polyethylene bags. 12 of these experimental bags received nutrients addition at time zero, while the others were kept without nutrient addition. The set bags which represented the enriched nutrient conditions were obtained by addition of a mixture of leucine (C and $\mathrm{N}$ ) and phosphate in order to maintain a substrate $\mathrm{C}: \mathrm{N}: \mathrm{P}$ molar ratio close to that of marine bacteria [26] as described in Bouvy et al. [24]. The bags with and without nutrient addition exhibited concentrations of $0.20 \mu \mathrm{M}$ and $0.07 \mu \mathrm{M}$ of $\mathrm{PO}_{4}$, respectively. The two levels of $\mathrm{P}$ concentration mimicked natural fluctuations in coastal lagoon waters. These concentrations were chosen to be relevant to phosphorus concentrations recently measured in Thau lagoon (a general decrease over the past 30 years has led to low values of soluble reactive phosphorus: i.e. from $3 \mu \mathrm{M}$ to undetectable values ( $<0.03 \mu \mathrm{M}$ in winter) [27]).

Since nutrients usually refer to inorganic nutrients, it should be noted that in this study, "nutrients" actually refer to "nutrients and organic source of C and N".

The incubation time (4 days) and experimental volume (2 L) were chosen to be consistent with the generation time of microorganisms, as validated in other experimental studies [28-31]. In the present study, the composition of unicellular eukaryotes was studied at T0 and T96h. The data provided by Bouvy et al. [24] regarding the evolution of abundances of the main biological communities (i.e. bacteria, viruses, heterotrophic flagellates) at 3 sampling times (T0, T48h, T96h) under the same experimental conditions as ours, informed this choice.

\section{Measurement of abiotic parameters}

Temperature was continuously measured using thermistor probes (Campbell Scientific 107). Incident UVBR $(280-320 \mathrm{~nm})$ was constantly monitored by a UVB radiometer (SKU 430, Skye instruments). During the experiment, temperature varied between $15.7^{\circ} \mathrm{C}$ and $17.2^{\circ} \mathrm{C}$ (and between $18.7^{\circ} \mathrm{C}$ and $20.2^{\circ} \mathrm{C}$ in ' $+3^{\circ} \mathrm{C}$ ' treatments), while incident UVB radiations $(280-320 \mathrm{~nm})$, which were measured around local zenith time, varied between 150 and $185 \mu \mathrm{Wcm}^{-2}$ (Table 1). At T0 and T96 h, samples were taken for abiotic analysis. A volume of $80 \mathrm{ml}$ of water was filtered on pre-combusted glass fiber filters (GF/F, Whatman) and stored at $-20^{\circ} \mathrm{C}$ until nitrate and phosphate concentrations were measured, following standard nutrient analysis methods [32].

\section{Bacterial and viral counting by flow cytometry}

At T0 and T96h, $5 \mathrm{ml}$ of water was collected from each of the polyethylene bags for flow cytometry counts. Picocyanobacteria, heterotrophic bacteria and viruses were counted using a FACSCalibur flow cytometry (Becton
Table 1 Environmental conditions (temperature, salinity, chlorophyll $a$ concentration, natural UVBR intensities) during the four days experiment

\begin{tabular}{|c|c|}
\hline \multicolumn{2}{|c|}{ Environmental conditions during the 4 days of study } \\
\hline Period & Spring (18-24 April) \\
\hline In situ Temperature & $15.7^{\circ} \mathrm{C}$ to $17.2^{\circ} \mathrm{C}$ \\
\hline In situ Salinity & Approx. 36 \\
\hline In situ Chl a & Approx. $1 \mu \mathrm{g} / \mathrm{L}$ \\
\hline $\begin{array}{l}\text { In situ maximum UVBR incidentsN } \\
\text { (local zenith time) }\end{array}$ & 150 to $185 \mu \mathrm{W} / \mathrm{cm} 2$ \\
\hline
\end{tabular}

Dickinson) equipped with an air-cooled laser providing $15 \mathrm{~mW}$ at $488 \mathrm{~nm}$. For photosynthetic-cells (i.e. picocyanobacteria) neither fixative nor fluorochrome were used. Samples were stored at $<4^{\circ} \mathrm{C}$ until analysis, which was performed within $2 \mathrm{~h}$ of sampling in field laboratories. Analysis was therefore performed on fresh samples, to which a suspension of $1-\mu \mathrm{m}$ beads (Molecular probes) was added, generally for 4 to 8 minutes in order to obtain $>20,000$ events. For the analysis of bacteria and viruses, $1 \mathrm{~mL}$ fixed (glutaraldehyde $0.5 \%$ final concentration) sub-samples were incubated with SYBR Green I (Molecular Probes, Eugene, OR, USA) at a final concentration of $1 / 10,000$ for $15 \mathrm{~min}$ at room temperature in the dark. The cytometry flow counts were performed as described in Brussard et al. [29].

\section{Small eukaryotes microscopy observation}

For enumeration of non-pigmented and pigmented eukaryotes, water samples $(100 \mathrm{~mL})$ taken at $\mathrm{T} 0$ and T96h were fixed with glutaraldehyde (1\% final concentration) and stored at $4^{\circ} \mathrm{C}$ for $24 \mathrm{~h} .20$ to $25 \mathrm{ml}$ of each preserved water sample was stained with DAPI (final concentration, $15 \mu \mathrm{g} \mathrm{mL}{ }^{-1}$ ) for $15 \mathrm{~min}$, filtered onto a black Nuclepore filter $\left(0.8 \mu \mathrm{m}\right.$-pore-size), stored at $-20^{\circ} \mathrm{C}$, and counted under an epifluorescence microscope with UV excitation (modified from Boenigk et al. [33]). Under UV light $(350 / 461 \mathrm{~nm})$, the eukaryotic cell nucleus appears as a separate organelle, while prokaryotic organisms appear as cells uniformly stained without visible nuclei. The blue and green light excitations were used to reveal pigmented cells.

\section{Molecular analysis of small eukaryotes Sampling and preservation}

Water samples from each treatment were taken at the beginning and at the end of the experiment. The microbial biomass was collected on $0.2 \mu \mathrm{m}$ pore size polycarbonate membranes (Millipore) under very low vacuum $(<20$ mbar) to prevent cell damage. Filters were then stored at $-80^{\circ} \mathrm{C}$ until nucleic acid extraction. 


\section{Nucleic acid extraction}

Nucleic acid extraction was performed as described by Lefranc et al. [34] and extracts were stored at $-20^{\circ} \mathrm{C}$ until analysis.

\section{Capillary electrophoresis - single strand conformation polymorphism (CE-SSCP)}

Nucleic acids from each sample were used as templates for PCR amplification of the 18S rRNA gene with primers Uni1392r (5'-ACG-GGC-GGT-GTG-TRC-3') labelled at the 5'-end with phosphoramidite [35] and Euk1209f (5'-CAG-GTC-TGT-GAT-GCC-CGC-3') [36]. Each $25 \mu \mathrm{L}$ reaction mixture contained $50 \mu \mathrm{M}$ of each primer, 1X Pfu reaction buffer, $20 \mathrm{mM}$ dNTPs, $1.0 \mathrm{U}$ of Pfu DNA polymerase (Promega) and $0.1 \mu \mathrm{g}$ of template DNA. PCR amplification was performed with a Rob cycler (Stratagene) under the following conditions: an initial denaturation step of $94^{\circ} \mathrm{C}$ for $2 \mathrm{~min}$, followed by 10 touchdown cycles of denaturation at $94^{\circ} \mathrm{C}$ for $1 \mathrm{~min}$, annealing at $65^{\circ} \mathrm{C}$ (with the temperature decreasing $1^{\circ} \mathrm{C}$ each cycle) for $1 \mathrm{~min}$, and extension at $72^{\circ} \mathrm{C}$ for $1 \mathrm{~min}$, followed by 15 cycles of $94^{\circ} \mathrm{C}$ for $1 \mathrm{~min}, 55^{\circ} \mathrm{C}$ for $1 \mathrm{~min}$ and $72^{\circ} \mathrm{C}$ for $1 \mathrm{~min}$, and a final elongation step at $72^{\circ} \mathrm{C}$ for $10 \mathrm{~min}$. The TET-labelled PCR products were quantified by visualization in ethidium bromide-stained agarose gels (2\%) and diluted in sterile TE (10 mM Tris, $1 \mathrm{mM}$ EDTA) in order to obtain around $10 \mathrm{ng} \mathrm{mL}^{-1}$ of PCR product. One $\mu \mathrm{L}$ of the dilution was mixed with $18.9 \mu \mathrm{L}$ of formamide (Applera Corp. Norwalk, Connecticut) and $0.1 \mu \mathrm{L}$ of the internal size standard GeneScan-400 Rox (Applied Biosystems), denatured at $94^{\circ} \mathrm{C}$ for 5 minutes, and immediately cooled on ice for $10 \mathrm{~min}$ utes before electrokinetic injection $(5 \mathrm{~s}, 12 \mathrm{kV})$ into a capillary tube $(47 \mathrm{~cm} \times 50 \mu \mathrm{m})$ filled with $5.6 \%$ of Gene Scan polymer in a ABI Prism 310 Genetic analyser (Applied Biosystems). Electrophoresis was carried out and data were collected as described in Sauret et al. [37].

\section{Eukaryotic rRNA genetic libraries}

Environmental DNA extracts were also used to construct the $18 \mathrm{~S}$ rRNA gene clone libraries. The eukaryote-specific primers Ek-1 F (5'-CTG-GTT-GATCCT-GCC-AG-3') and Ek-1520R (5-CYG-CAG-GTTCAC-CTA-C-3') were used for PCR amplification [38]. The PCR mixture $(50 \mu \mathrm{L})$ contained about $10 \mathrm{ng}$ of environmental DNA, $200 \mu \mathrm{M}$ of each deoxynucleoside triphosphate, $2 \mathrm{mM} \mathrm{MgCl} 2,10 \mathrm{pmol}$ of each primer, $1.5 \mathrm{U}$ of Taq DNA polymerase (Eurobio) and the PCR buffer supplied with the enzyme. Reactions were carried out in an automated thermocycler (MJ Research PTC 200cycler) with the following cycle: initial denaturation at $95^{\circ} \mathrm{C}$ for $5 \mathrm{~min}, 30$ cycles of denaturation at $95^{\circ} \mathrm{C}$ for $1 \mathrm{~min}$, annealing at $57^{\circ} \mathrm{C}$ for $1 \mathrm{~min}$, and extension at $72^{\circ} \mathrm{C}$ for $1 \mathrm{~min} 30 \mathrm{~s}$, and a final extension at $72^{\circ} \mathrm{C}$ for $10 \mathrm{~min}$.
PCR products (at least four $50 \mu \mathrm{L}$ samples) from the triplicate samples of each experimental condition were pooled, precipitated with ethanol-sodium acetate and resuspended in $50 \mu \mathrm{L}$ of sterile water. Clone libraries were constructed for the T0 control and for each of the eight treatments at T96 h using a TOPO TA cloning kit (Invitrogen, Carlsbad, CA) with PCR vector 2.1 according to the manufacturer's instructions.

\section{Phylogenetic analysis}

DOTUR was used to determine operational taxonomic units (OTUs) from $18 \mathrm{~S}$ sequences data [39] with a cutoff of $97 \%$ sequence similarity. To determine the phylogenetic affiliation, each sequence was first compared with sequences available in public databases using BLAST (National Center for Biotechnology Information and the Ribosomal Database Project) [40]. Secondly, the OTUs were aligned with complete sequences in an ARB database using the latter's automatic alignment tool (www.arb-home.de) [41]. The resulting alignments were checked and corrected manually. Sequences were inserted into an optimised tree according to the maximum parsimony criteria without allowing any changes to the existing tree topology (ARB software). The resulting tree was pruned to retain the closest relatives, sequences representative of eukaryotic evolution and our clones (Additional file 1: Figure S1). The sequences were screened for potential chimeric structures by using Chimera check from Ribosomal Database project II and by performing fractional treeing of the 5 ' and 3 ' ends of the sequenced DNA fragments. The sequences reported in this paper have been deposited into Genbank (accession numbers: HQ393974 to HQ394162).

The relative distribution of OTUs in the library was used to calculate coverage values (Good's coverage) [42] and the non-parametric richness estimator Chaol [43] and ACE [44] which are the most appropriate indices for microbial clone libraries [45].

\section{Statistical analysis \\ Univariate analysis}

We tested the homogeneity of the main biological parameters in experimental bags at the initial point (T0) of the experiment using an ANOVA test.

To test the effects of temperature, UV and nutrients on the abundance of all biological groups (bacteria, picocyanobacteria, viruses, heterotrophic flagellates and pigmented eukaryote abundances at T96 h), we used a three-way ANOVA test (with Bonferroni adjustment). Equality of the variances and normality of the residuals were tested by Bartlett and Shapiro-Wilk tests. The software Sigmastat ${ }^{\mathrm{TM}} 3.1$ was used for all analyses. 


\section{Multivariate analysis}

Indirect multivariate analysis was used to compare CESSCP fingerprinting. Total fingerprinting area was normalized between the different CE-SSCP profiles using the internal size standard Gene-Scan-400 Rox using the SAFUM software [46]. Similarity matrices based on Bray-Curtis distances, dendrograms (complete linkage clustering) and ordination by non-metric multidimensional scaling (MDS) were then obtained by using the PRIMER 5 software (PRIMER-E, Ltd., UK). One-way analysis of similarity (ANOSIM, Primer-E) was performed on the same distance matrix to test the null hypothesis that there was no difference between eukaryotic communities from replicate samples of each condition.

\section{Statistics applied to phylogenetic information}

From the sequencing results, the beta-diversity was studied from the Unifrac distance (fraction of the total branch length in the phylogeny that is unique to each environment) of each sample. In order to compare eukaryotic communities from the 9 genetic libraries Unifrac (http:// bmf2.colorado.edu/unifrac/index.psp; [47]) metrics were used to perform a principal coordinate analysis (PCA). The P-values matrix that compares each sample to each other sample was also performed from UNIFRAC metrics.

To investigate the relationships between changes in the eukaryote community structure (number of clones affiliated to each OTUs within main phylogenetic groups) and physic-chemical and biological parameters, we used direct multivariate canonical correspondence analysis (CCA) [48]. In addition to temperature values, UVB radiation, and nutrient concentrations, we considered the abundances of bacteria, picocyanobacteria, viruses, pigmented eukaryotes and heterotrophic flagellates as explanatory variables. CCA was calculated for the T96 h dataset using the Vegan package within the $\mathrm{R}$ software (http://cran.rproject.org/). A minimal set of explanatory variables associated with variation in eukaryote community structure was identified, allowing us to exclude the most redundant explanatory variables. Forward selection was performed to identify environmental variables that could explain a significant portion of the variation in small eukaryote structure $(\mathrm{P}<0.05)$ at T96 h. Eigen values for site scores, biplot and diversity data were plotted to illustrate the associations between these data [49].

\section{Results}

\section{Initial conditions}

\section{Biological and chemical parameters}

At T0, conditions were considered as homogeneous in all experimental bags. The statistical analysis showed no significant difference between experimental bags in terms of biological parameters (i.e. for bacterial, viral and small eukaryote abundances; mean values are presented in Table 2).

\section{Abundances and structure of the small eukaryotic community}

The microscope counts showed that the eukaryotic community was largely dominated by pigmented cells $(85.8 \%$ of total eukaryotes). Their mean abundance was $4.3 \times 10^{3}$ cells $\mathrm{mL}^{-1}$ and 13 of the 26 OTUs identified at T0 from sequencing results were affiliated to pigmented groups (Additional file 2: Table S1). Mamiellophyceae was the dominant group (nearly $83.7 \%$ of all pigmented eukaryotes observed by microscopy) and they were represented by 3 OTUs affiliated to Micromonas pusilla and Ostreococcus tauri (Figure 2 Additional file 2: Table S1). The microscope observations allowed detection of other Viridiplantae at low densities. In particular, some Pyramimonadales (genus Cymbomonas) were observed but were not recorded among sequences at T0. The mean relative abundance of Cryptophyceae (4 OTUs) was $10.9 \%$, while very low relative abundances of Bacillariophyceae (1 OTU) and Prymnesiophyceae (represented by Chrysochromulina-like cells, and 2 OTUs) were found by microscopy (Figure 2) and sequencing. Finally, Dinophyceae (cells larger than $6 \mu \mathrm{m}$ ) accounted for only 3\% of total pigmented eukaryotes abundance, and was represented by 1 OTU (Figure 2 Additional file 2: Table S1).

The mean abundance of non-pigmented eukaryotes was 776 cells $\mathrm{mL}^{-1}$ at T0, accounting for about $15 \%$ of total eukaryotes. In comparison to microscope counting, the proportion of typical non-pigmented eukaryotes was over-estimated in the clone library, accounting for $43.2 \%$ of total clones (such over-representation of non-

Table 2 Initial conditions for chemical and biological parameters

\begin{tabular}{|c|c|c|}
\hline \multicolumn{3}{|c|}{ Chemical and biological parameters in experimental bags at TO } \\
\hline & No nutrient addition & + Nutrient \\
\hline $\mathrm{PO}_{4} \mu \mathrm{M}$ & $0.07( \pm 0.01)$ & $0.2( \pm 0.01)$ \\
\hline $\mathrm{NO}_{3} \mu \mathrm{M}$ & $0.24( \pm 0.04)$ & $0.32( \pm 0.05)$ \\
\hline $\mathrm{NH}_{4} \mu \mathrm{M}$ & $0.48( \pm 0.04)$ & $\mathbf{0 . 4 4}( \pm 0.005)$ \\
\hline $\mathrm{NO}_{2} \mu \mathrm{M}$ & $\mathbf{0 . 0 4}( \pm 0.004)$ & $0.04( \pm 0.004)$ \\
\hline Bacteria $10^{6}$ cell $\mathrm{mL}^{-7^{*}}$ & $7.6( \pm 0.19)$ & $7.8( \pm 0.37)$ \\
\hline Virus $10^{8}$ cell $\mathrm{mL}^{-1 *}$ & $1.5( \pm 0.3)$ & $1.8( \pm 0.1)$ \\
\hline Picocyanobacteria $10^{3}$ cell $\mathrm{mL}^{-1 *}$ & $1.4( \pm 0.09)$ & $1.5( \pm 0.06)$ \\
\hline Non-pigmented Euk. $10^{2}$ cell $\mathrm{mL}^{-1}$ & $7.3( \pm 0.6)$ & $7.2( \pm 0.6)$ \\
\hline Pigmented Euk. $10^{3}$ cell $\mathrm{mL}^{-1}$ & $4.3( \pm 0.6)$ & $4.4( \pm 0.6)$ \\
\hline
\end{tabular}

Means values $( \pm \mathrm{SD})$ are presented for the two sets of experimental microcosms (with and without nutrient addition) at T0, for nitrogen and phosphorus compounds, bacteria, viruses, picocyanobacteria, non-pigmented and pigmented small eukaryotes.

* data obtained by flow-cytometry. 

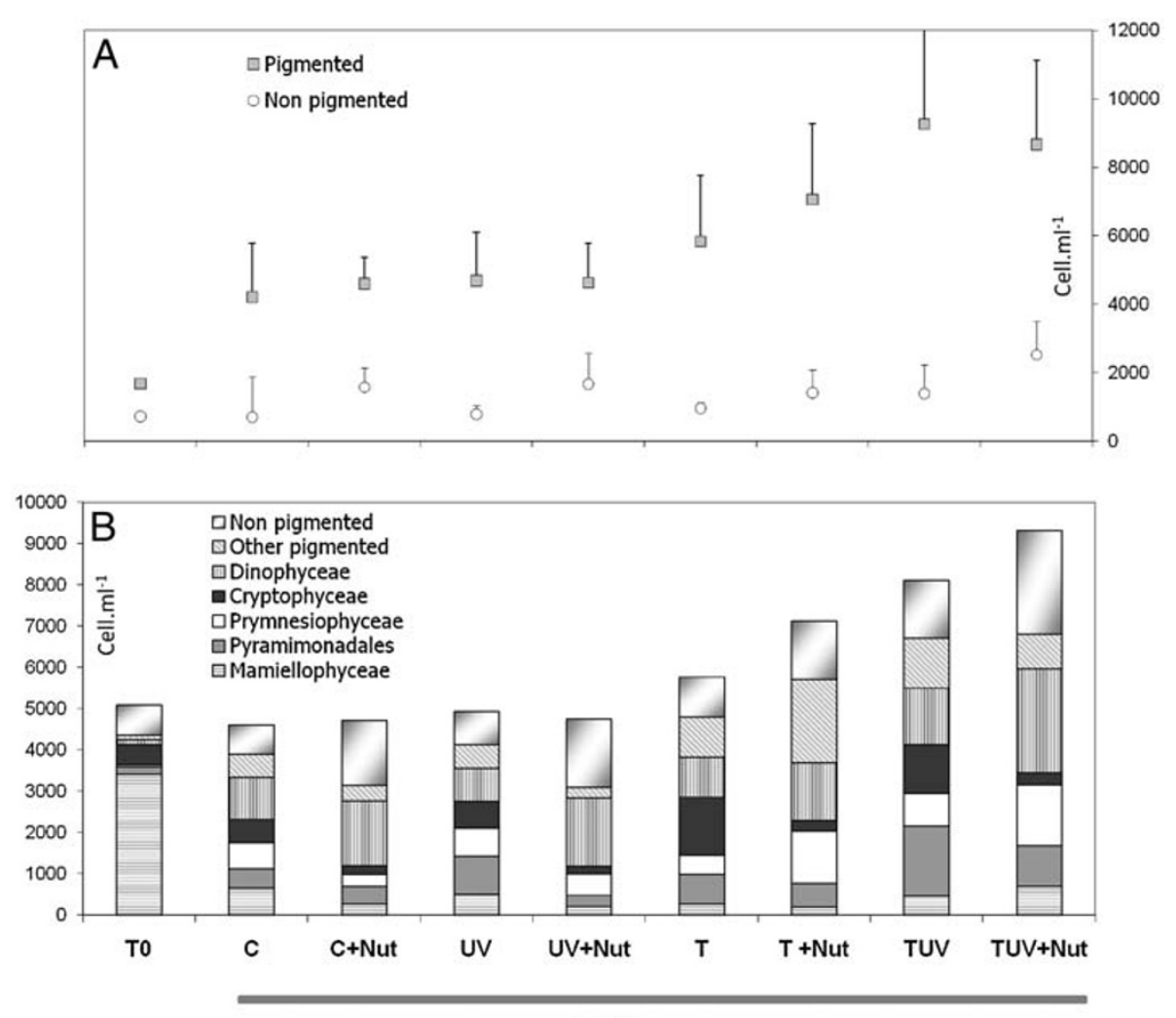

T 96h

Figure 2 A. Mean $( \pm S D)$ abundance of pigmented and non-pigmented small eukaryotes (cell $\mathrm{mL}^{-1}$ ) at T0 and T96 $\mathrm{h}$ in each treatment. Mean values and SD were calculated from values obtained from treatment triplicates. B. Relative abundance of different groups identified at T0 and T96 $\mathrm{h}$ in each treatment (data obtained from microscopic observation).

pigmented groups in 18S rRNA gene clone libraries has been discussed previously e.g.[50-52]). The diversity of these non-pigmented groups cannot be discriminated by classical microscopy due to a lack of distinct morphological features and/or their small size. However, from cloning-sequencing results, 11 different OTUs could be attributed to non-pigmented groups: Cercozoa (2 OTUs), Stramenopiles affiliated to Hyphochytrids (1 OTU), Syndiniales affiliated to Amoebophrya (2 OTUs), uncultured alveolates (4 OTUs), and Choanoflagellida (2 OTUs) (Figure 2 Additional file 2: Table S1).

\section{Changes in the small eukaryotes structure under UVBR, temperature and/or nutrient increase Changes in abundances}

At T96h, pigmented eukaryotes had abundances varying between $1.1 \times 10^{3}$ cells $\mathrm{mL}^{-1}(\mathrm{C})$ and $8.3 \times 10^{3}$ cells $\mathrm{mL}^{-1}$ (TUV) according to the treatment, and they still dominated small eukaryotes regardless of the treatment (Figure 2). All treatments with increased temperature were characterised by a significant increase in the density of pigmented eukaryotes $(\mathrm{p}<0.004$; Table 3; Figure 2).
Some major changes were observed in the relative proportions of the main taxonomic groups. The abundance of pigmented Dinophyceae increased in all treatments, with the highest increases where nutrients were added. Indeed, the 3-way ANOVA showed a significant effect of nutrients $(\mathrm{p}=0.028$, Table 3$)$. Inversely, for Cryptophyceae, a general negative impact of nutrient addition $(\mathrm{p}<0.001)$ counteracted the positive impact of temperature increase (Table 3, Figure 2). The relative abundance of Mamiellophyceae (Micromonas and Ostreococcus) decreased from T0 to T96h in all treatments, and they represented only between 0.1 and $14.8 \%$ of pigmented eukaryotes at the end of the experiment (depending on the treatment). Pyramimonadales seemed to take advantage of the general reduction of Mamiellophyceae densities and developed strongly, especially in treatments with increased UVBR. The 3-way ANOVA showed a positive impact of UVBR on Pyramimonadales abundance.

Non-pigmented eukaryotes (mainly free flagellated forms) tended to increase in abundance in all conditions. The highest values were found in TUV + Nut treatments (mean abundance: $2.5 \times 10^{3}$ cells $\mathrm{mL}^{-1}$ ), however, the 3- 
Table 3 Results of the three-way ANOVA performed from T96h abundance values

\begin{tabular}{|c|c|c|c|c|c|c|c|}
\hline Anova results $(\mathrm{P})$ & Temp & UV & Nut & Temp x UV & Temp x Nut & Temp x UV & Temp x UV x Nut \\
\hline Pigmented eukaryotes (total) cells $\mathrm{mL}^{-1}$ & $0.004(+)$ & NS & NS & NS & NS & NS & NS \\
\hline Mamiellophyceae & NS & NS & NS & NS & NS & NS & NS \\
\hline Pyramimonadales & $0.059(+)$ & $0.082(+)$ & NS & NS & NS & NS & NS \\
\hline Prymnesiophyceae & NS & NS & NS & NS & NS & NS & NS \\
\hline Cryptophyceae & $<0.001(+)$ & NS & $<0.001(-)$ & NS & 0.002 & NS & NS \\
\hline Bacillariophyceae & NS & NS & NS & NS & NS & NS & NS \\
\hline Dinophyceae & NS & NS & $0.028(+)$ & NS & NS & NS & NS \\
\hline Non-pigmented eukaryotes cells $\mathrm{mL}^{-1}$ & NS & NS & NS & NS & NS & NS & NS \\
\hline Bacteria cell $\mathrm{mL}^{-1}$ & $<0.001(+)$ & $0.013(-)$ & NS & NS & NS & NS & NS \\
\hline Virus particles $\mathrm{mL}^{-1}$ & $0.008(+)$ & $<0.001(-)$ & NS & 0.001 & NS & NS & NS \\
\hline Picocyanobacteria cells $\mathrm{mL}^{-1}$ & NS & NS & $<0.001(+)$ & NS & NS & NS & 0.013 \\
\hline
\end{tabular}

$\mathrm{P}$ values obtained for the effects of temperature (Temp), UVBR (UV), nutrient addition (Nut) and the interactions between the three factors are presented. + and signs indicate the direction of the effect (positive or negative impact). Bold font corresponds to significant values, where $p<0.05$, while normal font corresponds to a lower significance $(p<0.1)$. NS is the code for a non-significant effect.

way ANOVA did not reveal any significant impact of the manipulated factors (Table 3).

\section{Changes in small eukaryotes structure (CE SSCP)}

A Multidimensional Scaling (MDS) plot generated from Bray-Curtis similarity indices based on the $18 \mathrm{~S}$ rDNA CE-SSCP profiles, showed that all samples from temperature increase simulation (treatments $\mathrm{T}, \mathrm{T}+\mathrm{Nut}$, TUV, TUV + Nut) grouped in a separate cluster (Figure 3A). The small eukaryotic community structures of all other treatments (without temperature increase) had closer similarity to initial conditions. Overall, CESSCP profiles generated from all experimental bags showed good reproducibility within triplicate of each treatment (ANOSIM $\mathrm{R}<0.2, \mathrm{p}<0.001$ ), except for one replicate of the UVBR condition which had an atypical profile. MDS ordination plot stress value was low (0.1) which indicated good ordination without misleading interpretation [53]. The same trends were found with the UPGMA (Unweighted Pair Group Method using Arithmetic averages) analysis (data not shown).

\section{Changes in small eukaryotes phylogenetic composition (sequencing)}

A total of 88 OTUs were identified ( $97 \%$ similarity) (Additional file 2: Table S1; and phylogenetic tree in Additional file 1: Figure S1). During the incubation, the richness detected by molecular analyses showed a general decrease in 7 (out of the 8) treatments (Figure 4). TUV + Nut was the only treatment characterised by a clear increase in the richness $(\mathrm{SAce}=64)$, whereas the greatest decrease was recorded in the $\mathrm{C}+$ Nut treatment $($ SAce $=22)$. Even though no general trend was observed in the responses of small eukaryotes in terms of overall

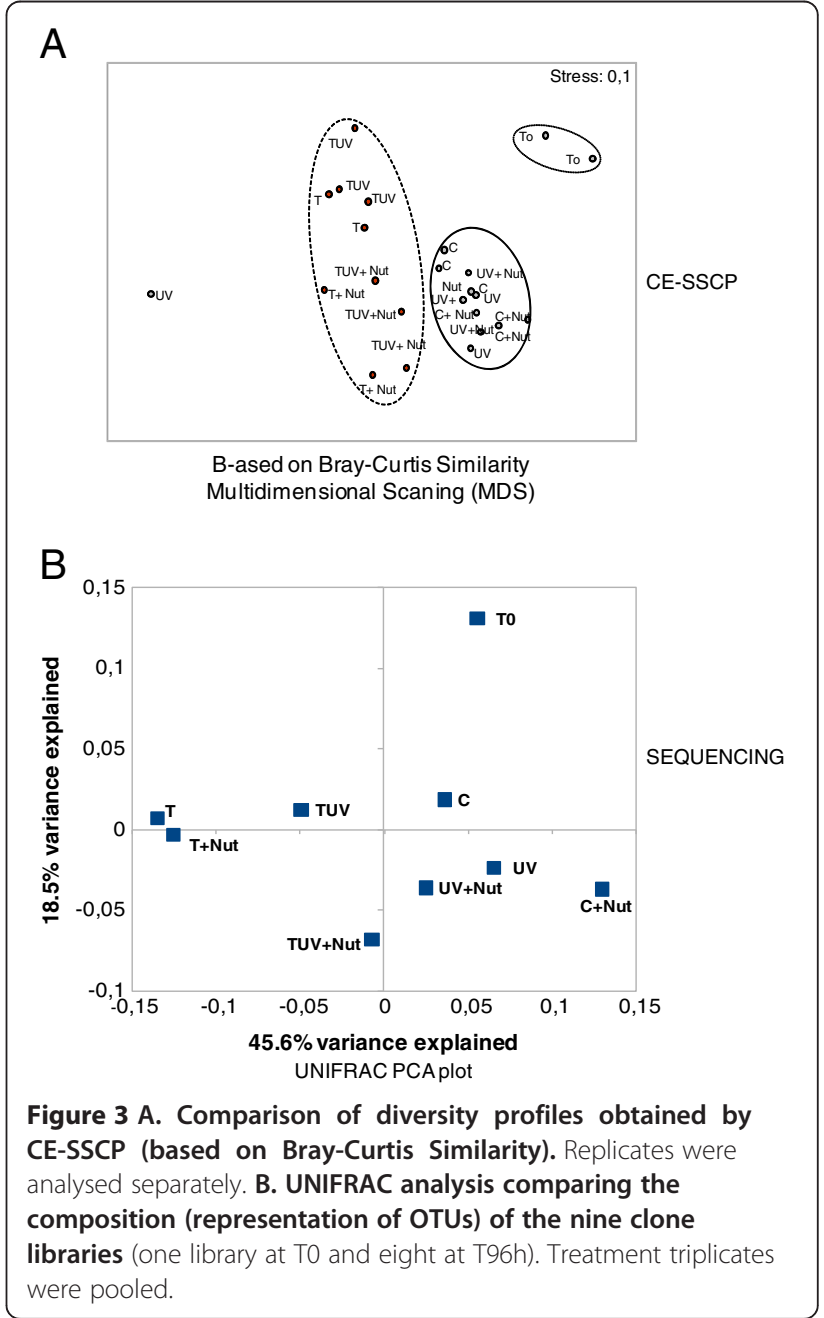




\begin{tabular}{|c|c|c|c|c|c|c|c|c|c|c|c|c|}
\hline & T0 & C & C+Nut & UV & UV+Nut & $\mathbf{T}$ & $\mathrm{T}+\mathrm{Nut}$ & TUV & TUV+Nut & & & \\
\hline $\mathrm{SCha}$ & 65 & 31 & 21 & 40 & 49 & 46 & 39 & 26 & 59 & & & \\
\hline SAce & 52 & 31 & 22 & 44 & 51 & 54 & 46 & 33 & 64 & & & \\
\hline Nb OTL & 526 & 20 & 21 & 18 & 25 & 25 & 19 & 18 & 25 & & & \\
\hline Nb clone & 46 & 36 & 39 & 33 & 43 & 66 & 46 & 32 & 37 & & & \\
\hline $100 \%$ & $\frac{87}{85}$ & $\frac{86}{80}$ & $\frac{88}{70}$ & $\begin{array}{l}85 \\
76\end{array}$ & 79 & $\begin{array}{l}\text { 觗 } \\
\text { 等 }\end{array}$ & $\begin{array}{l}79 \\
75\end{array}$ & 84 & $\begin{array}{l}84 \\
79\end{array}$ & $85-86$ & - & Uncultured eukaryotes \\
\hline $90 \%$ & ${ }_{73}^{74}$ & 79 & 60 & $\begin{array}{l}10 \\
75 \\
61\end{array}$ & $\begin{array}{l}68 \\
66 \\
65\end{array}$ & $\begin{array}{l}62 \\
81 \\
80\end{array}$ & $\begin{array}{l}71 \\
63\end{array}$ & 76 & $\begin{array}{l}79 \\
77 \\
72\end{array}$ & $\begin{array}{r}75-84 \\
58-78\end{array}$ & -1 & Ciliophora / Uncult Ciliates \\
\hline & 59 & $\begin{array}{l}76 \\
60\end{array}$ & 59 & 60 & 64 & 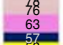 & 60 & 67 & $\begin{array}{l}71 \\
63\end{array}$ & 58 & - & $\begin{array}{l}\text { Uncultured Alveolates } \\
\text { Kinetoplastids }\end{array}$ \\
\hline $80 \%$ & 58 & 59 & 52 & & 60 & & & 63 & $\begin{array}{l}58 \\
55\end{array}$ & $50-56$ & 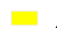 & Amoebophrya Syndiniales \\
\hline $70 \%$ & $\begin{array}{l}56 \\
52\end{array}$ & $\begin{array}{l}53 \\
52\end{array}$ & $\begin{array}{l}49 \\
43\end{array}$ & 59 & & & & & $\begin{array}{l}54 \\
53\end{array}$ & 43-49 & & Pigmented Dinophyceae \\
\hline & $\begin{array}{l}49 \\
44 \\
39 \\
39\end{array}$ & 49 & $\begin{array}{l}38 \\
37\end{array}$ & & & & 52 & 52 & & $\begin{array}{l}42 \\
40-41\end{array}$ & $\square$ & $\begin{array}{l}\text { Bicosocoeda } \\
\text { Labyrinthulids }\end{array}$ \\
\hline \& & $\begin{array}{l}39 \\
32 \\
31\end{array}$ & 37 & 36 & 52 & 52 & 52 & & 51 & 52 & $37-39$ & - & Hyphochytrids \\
\hline$\frac{\overline{0}}{0} 50 \%$ & $\begin{array}{l}27 \\
26\end{array}$ & & 35 & $\begin{array}{l}51 \\
50\end{array}$ & & & & $\begin{array}{l}47 \\
46\end{array}$ & 49 & $35-36$ & $\square$ & Pirsonia \\
\hline & $\begin{array}{l}24 \\
20 \\
17\end{array}$ & 36 & & $\begin{array}{l}49 \\
44\end{array}$ & $\begin{array}{l}51 \\
49 \\
48\end{array}$ & & & 43 & $\begin{array}{l}45 \\
44\end{array}$ & 34 & - & Acantharea \\
\hline $40 \%$ & 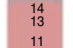 & ${ }_{30}^{35}$ & 34 & $\begin{array}{l}43 \\
40\end{array}$ & $\begin{array}{l}47 \\
46 \\
41\end{array}$ & & $\begin{array}{l}51 \\
49\end{array}$ & $\begin{array}{l}37 \\
35\end{array}$ & $\begin{array}{l}43 \\
42\end{array}$ & $\begin{array}{l}30-33 \\
26-29\end{array}$ & - & $\begin{array}{l}\text { Cercozoa } \\
\text { Choanoflagellida }\end{array}$ \\
\hline $30 \%$ & 9 & $\begin{array}{l}28 \\
17 \\
15\end{array}$ & ${ }_{30} 3$ & 37 & 37 & $\begin{array}{l}51 \\
50 \\
49 \\
45\end{array}$ & 47 & $\begin{array}{l}33 \\
21\end{array}$ & 37 & $21-25$ & ㅁ & Bacillariophyceae \\
\hline $20 \%$ & 7 & ${ }_{10}^{15}$ & $\begin{array}{l}25 \\
22\end{array}$ & 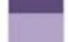 & 35 & $\begin{array}{l}\frac{93}{37} \\
36\end{array}$ & 37 & $\begin{array}{l}11 \\
15\end{array}$ & 35 & $17-20$ & - & Haptophyceae \\
\hline & & $\frac{9}{4}$ & $\begin{array}{l}19 \\
17\end{array}$ & 35 & & 17 & $\begin{array}{l}30 \\
30 \\
17\end{array}$ & 9 & $\begin{array}{l}34 \\
29\end{array}$ & $\begin{array}{l}-14 \\
1-3\end{array}$ & $\theta^{2}$ & Other Viridiplantae \\
\hline $10 \%$ & 4 & 6 & 2 & $\begin{array}{l}34 \\
25\end{array}$ & $\begin{array}{l}17 \\
12 \\
10\end{array}$ & 12 & $\begin{array}{l}16 \\
15 \\
12\end{array}$ & 6 & $\begin{array}{l}19 \\
19 \\
15\end{array}$ & $4,7,8$ & $\square$ & Mamiellophyceae \\
\hline $0 \%$ & & & 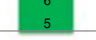 & 9 & 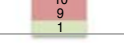 & 6 & 10 & & $\begin{array}{l}3 \\
5 \\
\end{array}$ & $5-6$ & - & Pyramimonadales \\
\hline & TO & C & C+Nut & UV & UV+Nut & $\mathbf{T}$ & T+Nut & TUV & TUV+Nut & & & \\
\hline \multicolumn{13}{|c|}{ T96h } \\
\hline $\begin{array}{l}\text { Figure } 4 \\
\text { diversity } \\
\text { S}_{\text {Chaol val }} \\
\text { are given }\end{array}$ & $\begin{array}{l}\text { mpc } \\
\text { DTUs } \\
\text { (rich }\end{array}$ & of th & $\begin{array}{l}\text { e } 18 \mathrm{Sr} \\
\text { s were } \\
\text { dd num } \\
\text { togram }\end{array}$ & $\begin{array}{l}\text { yene } \\
\text { ted), } \\
\text { f OTL }\end{array}$ & $\begin{array}{l}\text { ne libraries } \\
\text { ir affiliation } \\
\text { e specified }\end{array}$ & $\begin{array}{l}\text { ich his } \\
\text { ohylos } \\
\text { the tc }\end{array}$ & $\begin{array}{l}\text { am rep } \\
\text { ic grou } \\
\text { each h }\end{array}$ & $\begin{array}{l}\text { ts the } \\
\text { nd the } \\
\text { ram. A }\end{array}$ & $\begin{array}{l}\text { munity stru } \\
\text { Dortion of c } \\
\text { rily assigne }\end{array}$ & $\begin{array}{l}\text { ucture } \\
\text { clones } \\
\text { ed OTL }\end{array}$ & $\begin{array}{l}\text { expr } \\
\text { per } \\
\text { U ref }\end{array}$ & $\begin{array}{l}\text { ressed by the } \\
\text { OTU. The } S_{A C E} \text { and } \\
\text { ference numbers }\end{array}$ \\
\hline
\end{tabular}

richness, the beta-diversity (phylogenetic composition) studied from UNIFRAC metrics revealed a clear association between all treatments with increased temperature (discrimination on axis 1). This highlights the significant structuring impact of increased temperature, while on axis 2, nutrient addition appeared as the second-most important factor in shaping the eukaryotic composition (Figure 3B). These observations were confirmed by analyzing the correlations between coordinates on the PCA axis and environmental parameters: coordinates on axis 1 were indeed significantly correlated to temperature values $(P=0.006)$ while coordinates on axis 2 were significantly correlated to inorganic nutrients concentrations $\left(\mathrm{P}=0.046\right.$ and $\mathrm{P}=0.006$, respectively for $\mathrm{NO}_{2}$ and $\mathrm{NO}_{3}$ ). The P-values matrix that compares each sample to each other sample showed significant differences in the phylogenetic composition of eukaryotes between $\mathrm{T}$, $\mathrm{T}+$ Nut, TUV on the one hand and $\mathrm{C}+$ Nut on the other (Additional file 2: Table S2). Thus, CE-SSCP profiles and UNIFRAC analysis led to the same general pattern of changes in the small eukaryote structure.

The OTUs affiliated to non-pigmented taxa generally dominated the clone libraries (from $67.6 \%$ in $\mathrm{C}+\mathrm{Nut}$ to $85.3 \%$ in UV + Nut; Figure 4 and Additional file 2: Table $\mathrm{S} 1)$. Among them, Ciliates and uncultured Alveolates were generally well represented (accounting from 14 to $32 \%$ of total OTUs, and from 13 to $37 \%$ of clones, according to the treatments). However, the increase of non-pigmented group proportions within most of the libraries (compared to T0) was mainly linked to the emergence of taxa affiliated to parasitic groups: Hyphochytrids and genus Pirsonia (Heterokonta), and Amoebophrya (Alveolata).

The proportion of these sequences clearly increased during the incubation in all types of treatment. Parasitic taxa related to Amoebophrya particularly emerged in treatments with the highest temperatures $(\mathrm{T}, \mathrm{T}+\mathrm{Nut}$, TUV, and to a lesser extent TUV + Nut), while Hyphochytrids were strongly associated with all other treatments $(\mathrm{C}, \mathrm{C}+\mathrm{Nut}, \mathrm{UV}, \mathrm{UV}+\mathrm{Nut}$ ) (Figure 4). The CCA plot illustrates the significant link between the increase in temperature and the presence of numerous sequences affiliated to Amoebophrya, while sequences affiliated to Hyphochytrides have an opposite position in the plot (Figure 5). The potential hosts of Amoebophrya are primarily found within the class Dinophyceae, and it is noticeable that we observed a large number of pigmented Dinophyceae cells infected by parasites (multinucleated parasites in division in the cells) at T96 h in all types of treatment (data not shown). Pigmented Dinophyceae were indeed favored by the temperature increase but were also strongly positively affected by nutrient addition and UVBR increase (Figure 5). Pigmented 


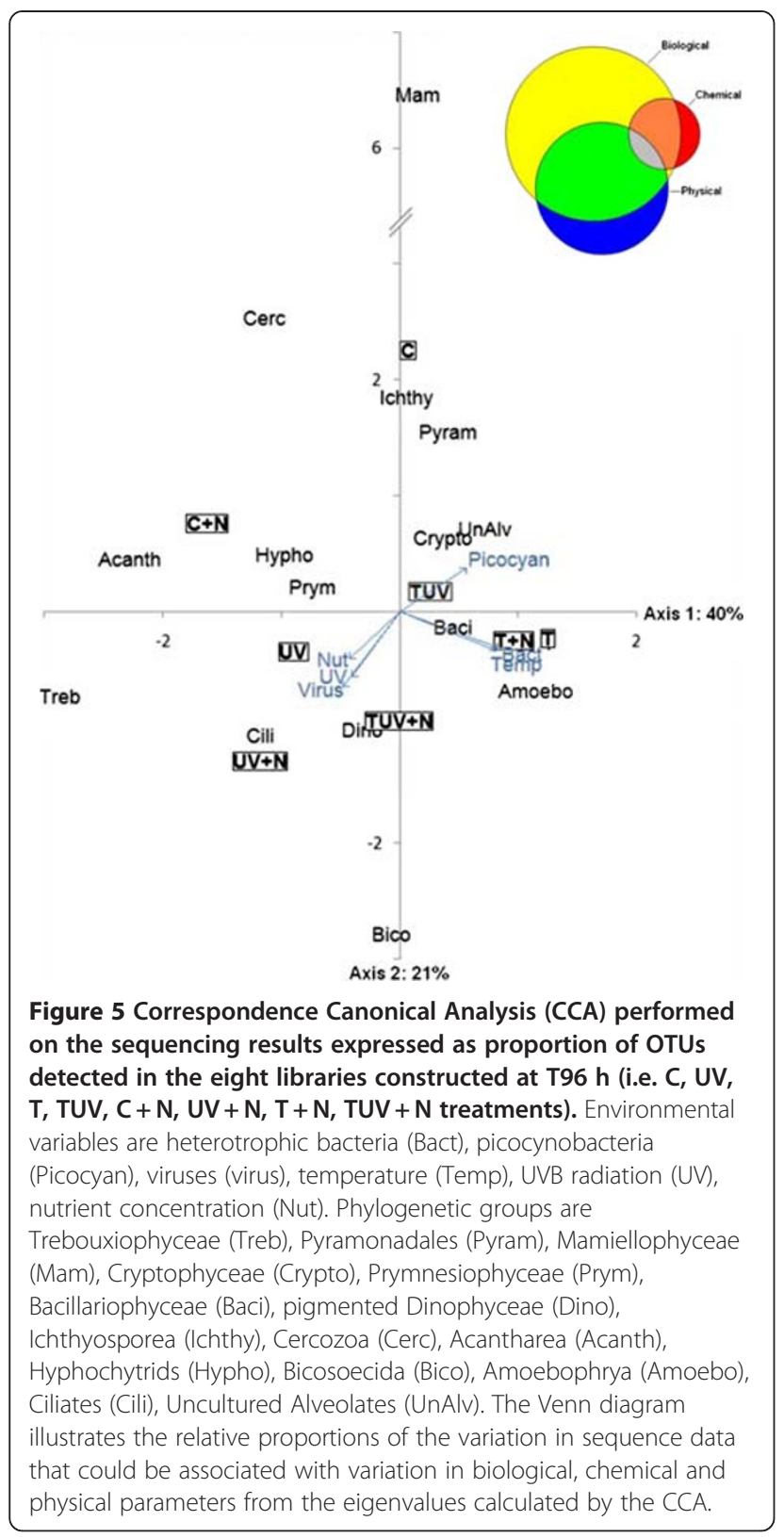

Dinophyceae and Amoebophrya were represented by 7 different OTUs each. Even though the presence/absence of these OTUs varied according to the treatments, no association between the abundance of host and parasite OTUs was observed.

The CCA supported the conclusion obtained from the UNIFRAC analysis, clearly showing that all treatments with increased temperature grouped together. Furthermore, the highest abundances of bacteria, picocyanobacteria, and pigmented groups such as Cryptophyceae and Bacillariophyceae were tightly associated with treatments receiving an increased temperature (Figure 5).

The CCA plot also illustrates the strong negative impact of experimental conditions on Mamiellophyceae in general. Mamiellophyceae represented 28\% of sequences in the clone library at T0, but were not detected at T96 h (except 1 OTU detected in the $\mathrm{C}$ treatments). In contrast, Pyramimonadales sequences (2 OTUs) appeared at T96 h in 6 out of the 8 types of treatment.

Overall, the analysis of the OTUs dynamics (either generally or for specific phylogenetic groups) showed that, even when the abundance of a given group did not change significantly from one treatment to another, some rearrangements could occur at the OTUs level (Additional file 2: Table S1). The CCA showed that $18.8 \%$ of the total variation in the eukaryotic structure was explained by temperature, whereas, UVBR and nutrients explained $11 \%$ and $8.4 \%$, respectively.

\section{Discussion}

The Thau lagoon, characterised by a high abundance of small eukaryotes and by recent in situ changes in phytoplankton structure due to water temperature increase [27], is an interesting ecosystem to investigate the responses of small eukaryotes to climatic and anthropogenic regulatory factors. Our experimentation does not intend to predict the impact of long-term global change on the structure of small planktonic eukaryotes. Indeed, only a combination of approaches including laboratory studies on model microbes, microcosm and mesocosm experiments, and in situ comparative studies would help to provide realistic predictions of the effects of environmental changes $[23,54]$. Our goal was to reveal the potential rapid responses of small eukaryote assemblage (using molecular and morphological methods) during the productive spring season when plankton may be particularly vulnerable to elevated temperature and UVBR [55].

Molecular analyses revealed the presence of various phylogenetic groups within the "black box" of small eukaryotes, especially non-pigmented eukaryotes (poorly discriminated by microscopy). Some limitations in the PCRbased methods are recognized, for instance, the overrepresentation of Alveolata (particularly Dinoflagellates and Ciliates) in 18S rRNA gene clone libraries due their high SSU rRNA gene copy number [50-52]. However, the molecular methods used here enabled the description of the diversity within dominant eukaryotic populations, and allowed examination of the effects of regulatory factors by considering both the dynamics of OTUs (using the sequencing and fingerprinting datasets) and the comparison of phylogenetic composition obtained for all treatments (using the sequencing data). The impact of temperature nutrients and UVBR explained $18.8 \%, 11.0 \%$ and $8.4 \%$ of the variance of the small eukaryotes structure respectively. While Bouvy et al. (2011) could not detect any significant responses of pico- or nano-eukaryotic plankton in the same experimental conditions, we demonstrated here, at a different taxonomic resolution, that small eukaryotes 
community structure was actually affected by this multifactorial pressure.

The simultaneous use of molecular and morphological methods was therefore essential to provide evidence of rapid shifts that occur at various taxonomic levels (abundance of large groups or community composition at OTU level) under the influence of temperature, UVBR and nutrient treatments.

Among the 3 regulatory factors tested, both sequencing and CE-SSCP demonstrated that increased temperature had the greatest influence on the small eukaryote community structure and composition. The single effect of temperature (without any significant interaction with UVBR and nutrients) on total pigmented eukaryote abundance was observed by microscopy. Considering the different phylogenetic groups within pigmented eukaryotes, complex interaction effects were also suggested. For instance, our results showed that under multi-factorial environmental changes, the general impact on the molecular diversity and abundance of pigmented Dinophyceae resulted from complex interactive (non-additive) effects. Multi-factorial interactions were also apparent for Cryptophyceae which experienced antagonistic effects of nutrient addition (significantly negative impact) and temperature (positive impact on relative abundance).

In addition to the manipulated factors (temperature, UVBR and nutrients), some biotic interactions such as predation, viral lysis and competition, are involved in the responses observed in this experiment. For example, the general reduction of Mamiellophyceae (Micromonas and Ostreococcus) in all treatments might be linked to (i) manipulation effects since these fragile cells might have been affected by filtration steps, (ii) limitation by inorganic nutrients under the rather low orthophosphate concentrations at T96h (from 0.05 to $0.08 \mu \mathrm{M}$ of $\mathrm{PO}_{4}$ ), (iii) the grazing impact of heterotrophic flagellates: these microorganisms are known to play a significant role in the regulation of Ostreococcus populations in the Thau lagoon [56] and were shown to exert a strong control of bacterioplankton during the study period [24]. We could not detect a link between the dynamics of Micromonas/ Ostreococcus and viruses. Since biological descriptors can explain some of the variance of small eukaryote phylogenetic structure, the observations made here regarding the effect of temperature, UVBR, and nutrients have to be considered in view of possible biological effects. Predation by zooplankton and competition with larger phytoplanktonic species were not considered in our size fractionated approach and should be taken into account, especially if long-term extrapolation of in situ responses of small eukaryotes is considered.

Our data provide further illustration of the need to consider the taxonomic and functional diversity of heterotrophic flagellates. The lack of discrimination between heterotrophic bacterivores and parasitic/saprotrophic zoospores within the non-pigmented flagellates can lead to misinterpretation of the functioning and responses of planktonic food webs. Indeed, while microscope observations did not allow us to detect changes in the abundance and structure of non-pigmented eukaryotes, a structuring impact of manipulated factors (especially temperature) was observed through sequencing results on taxa affiliated to parasitic and saprotroph groups (particularly Syndiniales and Hyphochytrids). The existence of eukaryotic parasites among small-size plankton was recently re-discovered by molecular environmental surveys, and the ecological significance of these groups has been highlighted by several authors $[57,58]$. The 'Fungi-like' Hyphochytrids possess many morphological and ecological similarities to chytrids $[58,59]$, and their role as saprotrophs and/or parasites is unclear [60,61], whereas the Amoebophrya are well recognized as a widely distributed parasitic order within the Dinophyceae [62]. Amoebophrya and Hyphochytrids emerged in clone libraries at T96 h and were presumably present among the rare species at T0. The taxa found to be phylogenetically close to Amoebophrya particularly emerged in treatments with increased temperature (Figure 5), along with their hosts (pigmented Dinoflagellates). This observation supports Guillou et al.'s [57] suggestion that warming could promote rapid infection cycles of Amoebophrya. However, broad extrapolation would need to take into account various aspects of the host-parasite relationships, such as the mechanisms underlying the parasitic specificity. In contrast to the Amoebophrya, hyphochytrids were associated with all treatments except those with increased temperature (Figure 5). From our results, we hypothesized that not only parasite communities, but also saprotroph communities would be shaped by temperature and UVBR conditions, as already described in other ecosystems [63]. The responses of saprotrophs to these drivers may result from direct and/or indirect effects as demonstrated in soils [64]; further research is probably needed on the saprotrophs in aquatic systems since changes in their assemblages may influence organic matter decomposition and nutrient cycling.

\section{Conclusion}

Even though caution should be exercised when applying the results of small-scale experiments to larger-scale systems, these results can be treated as an insight into ecological interactions that may occur in larger natural systems with more complex planktonic assemblages. Our results indicate that these ecosystem drivers, which are associated with climate change, and their interactions may cause changes in small eukaryotic community 
abundance and structure involving various functional groups including the small primary producers, parasites and saprotrophs. Notably, temperature tends to have a much greater effect on the community composition of small eukaryotes compared to UVBR (at least at the level tested in our experiment). Due to their strong link with other communities within the food web, the small eukaryotes variability may have potential consequences in food webs structure and energy flow. Currently, our knowledge of the potential for plankton in general and small eukaryotes in particular to adapt genetically and phenotypically to multifactorial physico-chemical climate drivers is poor. To improve our understanding, additional experimental investigations in other types of ecosystems and over longer periods of warming and UVBR exposure are required before generalization may be confidently applied. Future investigations should be based on the coupling of methods such as microscopy, flow cytometry, molecular analyses targeting several gene markers or fluorescence in situ hybridization in order to analyse the responses of the microbial community structure to multiple stressors at various taxonomic levels.

\section{Additional files}

\section{Additional file 1: Figure S1. Maximum parsimony tree showing} phylogenetic relationships of the partial $18 \mathrm{~S}$ rRNA gene sequences. The tree was constructed with the 376 sequences generated in this study and sequences from genbank. Only one representative sequence per OTU per library is presented in this phylogenetic tree. The labels show the origin of each sequence (treatments: $\mathrm{C}, \mathrm{C}+\mathrm{Nut}, \mathrm{UV}, \mathrm{UV}+\mathrm{Nut}, \mathrm{T}, \mathrm{T}+\mathrm{Nut}$, TUV, TUV+Nut, and, time: T0 and T96 h). Values in brackets correspond to the OTU numbers as presented in Figure 4 and Additional file 2: Table S1.

Additional file 2: Table S1. Composition of the nine 18S rRNA genes clone libraries in terms of OTUs at TO and T96h, the affiliation to phylogenetic groups is specified for each OTU. * The number associated to each OTU corresponds to numbers used in Figure 4 and in the phylogenetic tree (Additional file 1: Figure S1). Table S2. UNIFRAC metrics: The grey area (right panel) corresponds to the distance matrix obtained from the comparison of each pair of samples. Bold text denotes values in the upper quartile (i.e. most distant samples). The white area (left panel) corresponds to the P-values obtained by comparing each sample to each other sample. All P-values have been corrected for multiple comparisons by multiplying the calculated P-value by the number of comparisons made (Bonferroni correction). Bold text denotes significant $P$ values.

\section{Authors' contributions}

All authors have made substantial intellectual contributions to the study. They read and approved the final manuscript. TB was the principal investigator of this study. TB, ID, MB, SJ, JPT, YB, FV, BM, EL, EF participated in the experimental design. $B M, E L, T B$ supervised the operational realisation of the experiment. ID, HM, CB, EF, EL realised chemical (nutrients) and biological analyses (microscopic observations), SJ performed the flow cytometric analysis. JFG performed and interpreted the CE-SSCP analysis. CL, ID, DD performed the molecular analyses and the post sequencing analysis, AK contributed with $C L I D$ and $D D$ to the statistical analysis. Writing was mainly prepared by $I D, C L, D D$ and $M B$, helped by $A K$, JFG, SJ, FV, BM, YB, JPT, TB.

\section{Acknowledgements}

We gratefully acknowledge Jean Nouguier and Yvan Vergne for their technical help during the experiment. This study was supported by the French program PNEC (10301705 to TB) and the ANR AQUAPHAGE (ANR07 BIODIV 015-02 to TB). This work was also supported by the 'Groupement De Recherches (GDR) 2476 Réseaux Trophiques Pélagiques. The experimental platform for Mediterranean Ecosystem Research (MEDIMEER) was funded by UMR 5119 ECOLAG, CNRS-INEE, Institut Fédératif de Recherche 129 A. Sabatier, GDR 2476 Réseaux Trophiques Aquatiques, Région Languedoc Roussillon.

We thank Joseph Kirkman for improving the text.

\section{Author details}

${ }^{1}$ INRA, UMR 42 CARRTEL, 75 avenue de Corzent, BP511, Thonon-les-bains F-74200, France. ${ }^{2}$ Clermont Université, Université Blaise Pascal, CNRS, UMR 6023, LMGE, BP 10448, Avenue des Landais, Clermont Ferrand F-63000, France. ${ }^{3}$ Université Montpellier 2, UMR 5119 ECOSYM, CNRS, IRD, Ifremer, Université Montpellier 1, Place E Bataillon, cc 093, Montpellier cedex 5 34095, France. ${ }^{4}$ CNRS, UMR 7621, LOMIC, Observatoire Océanologique, Avenue de Fontaulé, Banyuls/mer F-66651, France. ${ }^{5}$ LIttoral ENvironnement et Sociétés (LIENSS) - UMR 6250, Université de La Rochelle, Institut du Littoral et de l'Environnement (ILE), 2 rue Olympe de Gouges, La Rochelle 17 000, France.

Received: 22 March 2012 Accepted: 27 August 2012

Published: 11 September 2012

\section{References}

1. Caron DA, Peele ER, Lim EL, Dennett MR: Picoplankton and nanoplankton and their trophic coupling in the surface waters of the Sargasso Sea south of Bermuda. Limnol Oceanogr 1999, 44:259-272.

2. Li WKW: Primary production of prochlorophytes, cyanobacteria and eucaryotic ultraphytoplankton: measurements from flow cytometric sorting. Limnol Oceanogr 1994, 39:169-175.

3. Moreira D, López-García P: The molecular ecology of microbial eukaryotes unveils a hidden world. Trends Microbiol 2002, 10:31-38.

4. Šlapeta J, Moreira D, Lopez-Garcia P: Global dispersal and ancient cryptic species in the smallest marine eukaryotes. Mol Biol Evol 2006, 23(1):23-29.

5. Lepère C, Boucher D, Jardillier L, Domaizon I, Debroas D: Succession and regulation factors of small eukaryote community composition in a lacustrine ecosystem (Lake Pavin). Appl Environ Microb 2006, 72:2971-2981.

6. Jardillier L, Zubkov MV, Pearman J, Scanlan DJ: Significant CO2 fixation by small prymnesiophytes in the subtropical and tropical northeast Atlantic Ocean. ISME J 2010, 4:1180-1192.

7. Cuvelier ML, Allen AE, Monier A, McCrow JP, Messie M, et al: Targeted metagenomics and ecology of globally important uncultured eukaryotic phytoplankton. PNAS 2010, 107(33):14679-14684.

8. Lepère C, Domaizon I, Debroas D: Unexpected importance of potential parasites in the composition of the freshwater small-eukaryote community. Appl Environ Microb 2008, 74:2940-2949.

9. Amaral-Zettler LA, McCliment EA, Ducklow HW, Huse SM: A method for studying protistan diversity using massively parallel sequencing of V Hypervariable Regions of Small-Subunit Ribosomal RNA genes. PLoS One 2009, 4(7):e6372.

10. Massana R, Unrein F, Rodriguez-Martinez R, Forn I, Lefort T, Pinhassi J, Not F: Grazing rates and functional diversity of uncultured heterotrophic flagellates. ISME J 2009, 3(5):588-596.

11. Shi XL, Marie D, Jardillier L, Scanlan DJ, Vaulot D: Groups without cultured representatives dominate eukaryotic picophytoplankton in the oligotrophic South East Pacific Ocean. PLoS One 2009, 4(10):e7657.

12. Evans $C$, Archer SD, Jacquet $S$, Wilson WH: Direct estimates of the contribution of viral lysis and microzooplankton grazing to the decline of a Micromonas spp population. Aquat Microb Ecol 2003, 30:207-219.

13. Baudoux AC, Veldhuis MJW, Noordeloos AAM, Vann Noort G, Brussaard CPD: Estimates of virus-vs grazing induced mortality of picophytoplankton in the North Sea during summer. Aquat Microb Eco 2008, 52:69-82

14. Chen M, Chen F, Zhao B, Wu QL, Kong FX: Genetic diversity of eukaryotic microorganisms in Lake Taihu, a large shallow subtropical lake in China. Microb Ecol 2008, 56(3):572-583 
15. Masquelier S, Foulon E, Jouenne F, Ferréol M, Brussard CPD, Vaulot D: Distribution of eukaryotic in the English Channel and North Sea in summer. J Sea Res 2011, 66:111-122.

16. Petchey OL, McPhearson PT, Casey TM, Morin PJ: Environmental warming alters food-web structure and ecosystem function. Nature 1999, 402:69-72.

17. Mostajir B, Sime-Ngando T, Demers S, Belzile C, et al: Ecological implications of changes in cell size and photosynthetic capacity of marine Prymnesiophyceae induced by ultraviolet-B radiation. Mar Ecol Prog Ser 1999, 187:89-100.

18. Sommaruga R, Hofer JS, Alonso-Saez L, Gasol JM: Differential Sunlight Sensitivity of Picophytoplankton from Surface Mediterranean Coastal Waters. Appl Environ Microb 2005, 71(4):2154-2157.

19. Ferreyra GA, Mostajir $B$, Schloss IR, Chatila K, Ferrario ME, Sargian P, Roy $S$, Prod'homme J, Demers S: Ultraviolet-B radiation effects on the structure and function of lower trophic levels of the marine planktonic food web. Photochem Photobiol 2006, 82(4):887-897.

20. Conan P, Joux F, Torréton JP, Pujo-Pay M, Rochelle-Newall E, Mari X: Impact of solar ultraviolet radiation on bacterio- and phytoplankton activity in a large coral reef lagoon (SW New Caledonia). Aquat Microb Ecol 2008, $52: 83-98$.

21. Christensen MR, Graham MD, Vinebrooke RD, Findlay DL, Paterson MJ, Turner MA: Multiple anthropogenic stressors cause ecological surprises in boreal lakes. Global Change Biol 2006, 12(12):2316-2322.

22. Vidussi F, Mostajir B, Fouilland E, Le Floc'h E, et al: Effects of experimental warming and increased ultraviolet $B$ radiation on the Mediterranean plankton food web. Limnol Oceanogr 2011, 56(1):206-218.

23. Doyle SA, Saros JE, Williamson CE: Interactive effects of temperature and nutrient limitation on the response of alpine phytoplankton growth to ultraviolet radiation. Limnol Oceanogr 2005, 50(5):1362-1367.

24. Bouvy M, Bettarel $Y$, Bouvier C, Domaizon I, Jacquet $S$, LeFloc'h E, Montanié H, Mostajir B, Sime-Ngando T, Torréton JP, Vidussi F, Bouvier T: Trophic interactions between viruses, bacteria, and nanoflagellates under various nutrient conditions and simulated climate change. Environ Microbiol 2011, 13(7):1842-1857

25. Nouguier J, Mostajir B, Le Floc'h E, Vidussi F: An automatically operated system for simulating global change temperature and ultraviolet $B$ radiation increases: application to the study of aquatic ecosystem responses in mesocosm experiments. Limnol Oceanog Methods 2007, 5:269-279.

26. Goldman JC, Caron DA, Dennet MR: Regulation of gross efficiency and ammonium regeneration in bacteria by C:N ratio. Limnol Oceanogr 1987 32:1239-1252.

27. Collos Y, Gagne C, Laabir M, Vaquer A, Cecchi P, Souchu P: Nitrogenous nutrition of Alexandrium catenella (Dinophyceae) in cultures and in Thau lagoon, southern France. J Phycol 2004, 40(1):96-103.

28. Jardillier L, Boucher D, Personnic S, Jacquet S, Thenot A, Sargos D, Amblard C, Debroas D: Relative importance of nutrients and mortality factors on prokaryotic community composition in two lakes of different trophic status: Microcosm experiments. FEMS Microbiol Ecol 2005, 53(3):429-443.

29. Brussard CPD, Marie D, Bratbak G: Flow cytometric detection of viruses. J. Virological methods 2000, 85:175-182.

30. Pradeep RAS, Sime-Ngando T: Functional responses of prokaryotes and viruses to grazer effects and nutrient additions in freshwater microcosms. ISME J 2008, 2:498-509.

31. Bonilla-Findji O, Herndl GJ, Gattuso JP, Weinbauer MG: Viral and flagellate control of prokaryotic production and community structure in Offshore Mediterranean Waters. Appl Environ Microb 2009, 75(14):4801-4812.

32. Tréguer P, LeCorre P: Manuel d'analyse des sels nutritifs dans l'eau de mer. Utilisation de l'AutoAnalyser II Technicon. 2nd edition. Brest, France: Univ. Bretagne Occidentale, Laboratoire de Chimie marine; 1975.

33. Boenigk J, Stadler P, Wiedlroither A, Hahn MW: Strain-specific differences in the grazing sensitivities of closely related ultramicrobacteria affiliated with the Polynucleobacter Cluster. Appl Environ Microb 2004, 70(10):5787-5793.

34. Lefranc M, Thénot A, Lepère C, Debroas D: Genetic diversity of small eukaryotes in lakes differing by their trophic status. Appl Environ Microb 2005, 71:5935-5942.

35. Lane DJ, Pace B, Olsen GJ, Stahl DA, Sogin ML, Pace NR: Rapid determination of $16 \mathrm{~S}$ ribosomal RNA sequences for phylogenetic analyses. PNAS 1985, 82:6955-6959.
36. Giovannoni SJ, DeLong EF, Olsen GJ, Pace NR: Phylogenetic group-specific oligodeoxynucleotide probes for identification of single microbial cell. $J$ Bacteriol 1988, 170:720-726.

37. Sauret C, Christaki U, Moutsaki P, Hatzianestis I, Gogou A, Ghiglione JF: Influence of pollution history on the response of coastal bacterial and nanoeukaryote communities to crude oil and biostimulation assays. Mar Environ Res 2012, 79:70-78.

38. Lopez-Garcia P, Philippe H, Gail F, Moreira D: Autochthonous eukaryotic diversity in hydrothermal sediment and experimental microcolonizers at the Mid-Atlantic Ridge. PNAS 2003, 100(2):697-702.

39. Schloss PD, Handelsman J: Introducing DOTUR, a computer program for defining operational taxonomic units and estimating species richness. Appl Environ Microb 2005, 71(3):1501-1506.

40. Altschul SF, Madden TL, Schäffer AA, Zhang J, Zhang Z, Mille W, Lipman DJ: Gapped BLAST and PSIBLAST: a new generation of protein database search programs. Nucleic Acids Res 1997, 25:3389-3402.

41. Ludwig W, Strunk O, Westram R, Richter $L$, et al: ARB: a software environment for sequence data. Nucleic Acids Res 2004, 32:1363-1371.

42. Hughes JB, Hellmann JJ, Ricketts TH, Bohannan BJ: Counting the uncountable: Statistical approaches to estimating microbial diversity. Appl Environ Microbiol 2001, 67(10):4399-4406.

43. Chao A: Nonparametric estimation of the number of classes in a population. Scandinavian J Stat 1984, 11:265-270.

44. Chao A, Lee SM: Estimating the number of classes via sample coverage. J Am Stat Assoc 1992, 87:210-217.

45. Kemp PF, Aller JY: Estimating prokaryotic diversity: When are 16S rDNA libraries large enough? Limnol Oceanogr: Methods 2004, 2:114-125.

46. Zemb O, Haegeman B, Delgenes JP, Lebaron P, Godon JJ: Safum: statistical analysis of SSCP fingerprints using PCA projections, dendrograms and diversity estimators. Mol Ecol Notes 2007, 7:767-770.

47. Lozupone C, Knight R: UniFrac: a new phylogenetic method for comparing microbial communities. Appl Environ Microb 2005, 71(12):8228-8235.

48. ter Braak CJF: Canonical correspondence analysis: a new eigenvector technique for multivariate direct gradient analysis. Ecology 1986 67:1167-1179.

49. Legendre P, Legendre L: Numerical ecology. Amsterdam: 2nd English edition Elsevier Science BV; 1998.

50. Not F, del Campo J, Balagué V, de Vargas C, Massana R: New Insights into the Diversity of Marine Picoeukaryotes. PLOS ONE 2009, 4:e7143.

51. Shi XL, Lepère C, Scanlan DJ, Vaulot D: Plastid 16S rRNA Gene Diversity among Eukaryotic Picophytoplankton Sorted by Flow Cytometry from the South Pacific Ocean. PLOS ONE 2011, 6(4):e18979.

52. Lepère C, Masquelier S, Mangot JF, Debroas D, Domaizon I: Vertical distribution of small eukaryote diversity in lakes: a quantitative approach. The ISME Journal 2010, 4:1509-1519.

53. Clarke KR, Warwick R: Change in Marine Communities: An Approach to Statistical Analysis and Interpretation. Plymouth, UK: 2nd edition: PRIMER-E; 2001.

54. Joint I, Donay SC, Karl DM: Will ocean acidification affect marine microbes? The ISME J 2011, 5:1-7

55. Joint I, Jordan MB: Effect of short-term exposure to UVA and UVB on potential phytoplanlton production in UK coastal waters. J Plankton Res 2008, 3052:199-210.

56. Bec B, Husseini-Ratrema J, Collos Y, Souchu P, Vaquer A: Phytoplankton seasonal dynamics in a Mediterranean coastal lagoon: emphasis on the picoeukaryote community. J Plankton Res 2005, 27(9):881-894.

57. Guillou L, Alves-de Souza C, Siano R, Gonzalez H: The ecological significance of small eukaryotic parasites in marine ecosystems. Microbiol Today 2010, 92-95. http://www.sgm.ac.uk/pubs/micro_today/about.cfm.

58. Lefèvre E, Roussel B, Amblard C, Simé-Ngando T: The molecular diversity of freshwater picoeukaryotes reveals high occurrence of putative parasitoids in the plankton. PLOS ONE 2008, 3:2324-2333.

59. Hausner $G$, Inglis $G$, Yanke $L$, Kawchuk LM, McAllister TA: Analysis of restriction fragment length polymorphisms in the ribosomal DNA of a selection of anaerobic chytrids. Can J Bot 2000, 78(7):917-927.

60. Alster A, Zohary T: Interactions between the bloom-forming dinoflagellate Peridinium gatunense and the chytrid fungus Phlyctochytrium sp. Hydrobiologia 2007, 578(1):131-139.

61. Ibelings B, Arnout De Bruin W, Kagami M, Rijkeboer M, Brehm M, Van D, Ibelings B, Arnout De Bruin W, Kagami M, Rijkeboer M, Brehm M, Van Donk 
E: Host parasite interactions between freshwater phytoplankton and chytrid fungi (chytridiomycota). J Phycol 2004, 40:437-453.

62. Guillou L, Viprey M, Chambouvet A, Welsh RM, Kirkham AR, Massana R, Scanlan DJ, Worden AZ: Widespread occurrence and genetic diversity of marine parasitoids belonging to Syndiniales (Alveolata). Environ Microiol 2008, 10(12):3349-3365.

63. Reuder J, Dameris M, Koepke P: Future UVradiation in Central Europe modeled from ozone scenarios. J Photoch Photobio B 2001, 61:94-105.

64. Duguay KJ, Kliromonos JN: Direct and indirect effects of enhanced UV-B radiation on the decomposing and competitive abilities of saprobic fungi. Applied Soil Ecol 2000, 14(2):157-164.

doi:10.1186/1471-2180-12-202

Cite this article as: Domaizon et al: Short-term responses of unicellular planktonic eukaryotes to increases in temperature and UVB radiation. BMC Microbiology 2012 12:202.

\section{Submit your next manuscript to BioMed Central and take full advantage of:}

- Convenient online submission

- Thorough peer review

- No space constraints or color figure charges

- Immediate publication on acceptance

- Inclusion in PubMed, CAS, Scopus and Google Scholar

- Research which is freely available for redistribution 